OPEN ACCESS

Edited by:

Benyi Li,

University of Kansas Medical Center,

United States

Reviewed by:

Rohan Garje,

The University of lowa, United States

Brian James Davis,

Mayo Clinic College of Medicine and

Science, United States

*Correspondence:

Stéphane Supiot

Stephane.supiot@ico.unicancer.fr

Specialty section:

This article was submitted to

Genitourinary Oncology,

a section of the journal

Frontiers in Oncology

Received: 21 September 2021 Accepted: 30 November 2021

Published: 24 December 2021

Citation:

Cailleteau A, Sargos P, Saad F, Latorzeff I and Supiot S (2021) Drug Intensification in Future

Postoperative Radiotherapy

Practice in Biochemically-Relapsing

Prostate Cancer Patients.

Front. Oncol. 11:780507.

doi: 10.3389/fonc.2021.780507

\section{Drug Intensification in Future Postoperative Radiotherapy Practice in Biochemically-Relapsing Prostate Cancer Patients}

\author{
Axel Cailleteau ${ }^{1}$, Paul Sargos ${ }^{2}$, Fred Saad ${ }^{3}$, Igor Latorzeff ${ }^{4}$ and Stéphane Supiot ${ }^{1,5 *}$ \\ ${ }^{1}$ Department of Radiation Oncology, Institut de Cancérologie de l'Ouest, Nantes Saint-Herblain, France, ${ }^{2}$ Department of \\ Radiation Oncology, Institut Bergonié, Bordeaux, France, ${ }^{3}$ Department of Urology, Université de Montréal, Montreal, QC, \\ Canada, ${ }^{4}$ Department of Radiation Oncology, Oncorad Clinique Pasteur, Toulouse, France, ${ }^{5}$ University of Nantes, CRCINA \\ (CNRS, Inserm), Nantes, France
}

Although salvage prostate bed radiotherapy is highly effective in biochemically-relapsing prostate cancer patients following prostatectomy, relapses remain frequent and improvements are needed. Randomized phase 3 trials have shown the benefit of adding androgen-depriving therapy to irradiation, but not all patients benefit from this combination. Preclinical studies have shown that novel agents targeting the androgen receptor, DNA repair, PI3K/AKT/mTOR pathways, or the hypoxic microenvironment may help increase the response to prostate bed irradiation while minimizing potential side effects. This perspective review focuses on the most relevant molecules that may have an impact when combined with salvage radiotherapy, and underlines the strategies that need to be developed to increase the efficacy of salvage post-prostatectomy radiotherapy in prostate cancer patients.

Keywords: radiosensitizing agents, PARP inhibitors, androgen receptor (AR) antagonist, combined treatment, salvage prostate bed radiotherapy

\section{INTRODUCTION}

Despite adequate surgery, biochemical relapse following prostatectomy for locally advanced prostate cancer occurs in up to $50 \%$ of cases (1). One interesting result of adjuvant radiotherapy trials is that treatment failure is mainly a result of lack of local control $(2,3)$. This corroborates the results of salvage radiotherapy trials that showed that prostate bed radiotherapy is efficient in most cases, suggesting that the invisible relapsing cells are mostly located within the prostate bed $(4,5)$. In cases of biochemical relapse, it is currently recommended that the prostate bed be irradiated before the PSA reaches $0.5 \mathrm{ng} / \mathrm{ml}$ (6), as a higher risk of relapse has been shown in patients with more than this threshold (7). Radiotherapy also plays a role in the management of metastatic lymph nodes $(8,9)$. The NRG Oncology/RTOG 0534 SPPORT Trial showed that irradiating the pelvic lymph nodes in addition to the prostate bed improved progression-free survival compared to the prostate bed alone (10). This important result could be interpreted as radiotherapy being capable not only of reducing local relapses but also of slowing down or even blocking the metastatic process. Altogether, these 
findings have led to a new appreciation of local and regional control as a determining factor in survival and emphasize the role of combined modality approaches in the treatment of biochemically-relapsing prostate cancer.

Despite adequate salvage prostate bed radiotherapy, retrospective studies suggest that relapses following this technique are still localized in the prostate bed in up to $22 \%$ of patients (11-13), which suggests that combatting radioresistance pathways may decrease relapse rates. Moreover, after prostate bed radiotherapy, most relapses occur within the patients' pelvic lymph nodes (11-13). The dose of radiotherapy to the pelvic lymph nodes is limited by the vicinity of the small bowel. Therefore, the maximum dose to the whole pelvic lymph node is limited to $54-55 \mathrm{~Gy}$ in conventional fractionation $(14,15)$. This dose is lower than the dose usually validated to eradicate microscopic tumor cells within the prostate bed (60 to $66 \mathrm{~Gy}$ ) (1), which further reinforces the need to biologically escalate the dose to the pelvic lymph nodes by adding radiosensitizing agents.

To improve the efficacy of post-prostatectomy radiotherapy both locally and distantly, androgen-depriving therapy is one partner of choice as it can radiosensitize prostate cancer cells by both reducing the hypoxic fraction (16) and decreasing testosterone-induced increased DNA repair mechanisms (17, 18). Two major studies combined ADT with radiotherapy to the prostate bed $+/$ - pelvic lymph nodes $(4,5)$. Both studies showed improved biochemical relapse-free survival, metastasisfree survival and even overall survival in the RTOG 9601 study $(4,5)$. The recommendation is now to combine ADT and postprostatectomy radiotherapy in patients with a high risk of biochemical relapse following prostatectomy (6).

Despite combined ADT and irradiation, up to 30\% may relapse at 10 years $(4,5)$. To improve survival, one major area of research is to combine irradiation with active drugs capable of inhibiting micrometastatic cells outside the pelvis, thus improving metastatic control, and ideally also capable of targeting radioresistance pathways to decrease locoregional relapses. The mechanisms behind the aggressiveness and radioresistance of prostate cancer are progressively being

\footnotetext{
Abbreviations: DNA, deoxyribonucleic acid; PI3K, phosphatidylinositol 3kinases; AKT, protein kinase B; mTOR, mammalian target of rapamycin; NRG, cancer clinical cooperative group including the National Surgical Adjuvant Breast and Bowel Project (NSABP), the Radiation Therapy Oncology Group (RTOG), and the Gynecologic Oncology Group (GOG); SPPORT, short term androgen deprivation with pelvic lymph node or prostate bed only radiotherapy; ADT, androgen-depriving therapies; DLT, dose-limiting toxicity; ARE, androgen response element; ETS, erythroblast transformation-specific; AR, androgen receptor; DHT, di-hydrotestosterone; LH-RH, luteinising hormone-releasing hormone; CYP17A1, cytochrome P450 17A1; TMPRSS2, transmembrane protease, serine 2; ERG, ETS-related gene; hK2, hexokinase 2; GETUG, groupe d'étude des tumeurs urogénitales; CARLHA, combined abiraterone, radiotherapy and LH-RH agonists; AA, abiraterone acetate; SRT, salvage radiotherapy; PTEN, phosphatase and tensin homolog; RAS, rat sarcoma virus protein; RAF, rapidly accelerated fibrosarcoma serine/threonine-protein kinase; MEK, mitogenactivated protein kinase; ERK, extracellular signal-regulated kinases; VEGF, vascular endothelial growth factor; DNA-PK, DNA-dependent protein kinase; DDR, DNA damage response; BRCA2, breast cancer 2; BER, base excision repair; PARPi, polyADP ribosylpolymerase inhibitors; SAKK, Die Schweizerische Arbeitsgemeinschaft für Klinische Krebsforschung; PSA, prostate-specific antigen.
}

revealed. Localized hormone-sensitive prostate cancer is a highly heterogeneous disease (19). Large genomic and transcriptomic studies highlighted several major mechanisms of aggressiveness relating to either the tumor itself $(20,21)$ or its microenvironment $(22,23)$, but specific information regarding the genomic mechanisms of radioresistance in prostate cancer is scarce $(24,25)$. Although several studies have reported histological factors that predict survival after radiotherapy to the intact prostate gland [reviewed in $(26,27)]$, less information is available on predicting relapse after prostate bed radiotherapy. Recent transcriptomic analyses have described the first test capable of distinguishing low- and high-risk biochemicallyrelapsing forms of prostate cancer (28). These genomic and transcriptomic analyses can help identify novel mechanisms in prostate cancer progression, and suggest radiosensitizing drugs that target DNA repair, survival pathways, or the tumor microenvironment (29). Based on this better understanding of the mechanisms behind the aggressiveness and radioresistance of prostate cancer, this article describes current and future strategies for drug intensification that aim to improve the efficacy of post-prostatectomy radiotherapy.

\section{Targeting Microtubule Assembly}

In a first attempt to increase the efficacy of prostate bed radiotherapy, multiple studies tried to combine chemotherapeutic agents, such as docetaxel or cabazitaxel, which target microtubule assembly. The combination of docetaxel/prednisone and sunitinib prior to salvage radiotherapy was evaluated in biochemicallyrelapsing prostate cancer patients (30) (Table 1). This study had to be stopped because of excess dose-limiting toxicity (DLT). The progression-free survival rate at 2 years was $51 \%$. Weekly docetaxel combined with prostate bed radiotherapy was better tolerated, but grade 3 neutropenia was noted in almost $50 \%$ of patients in a small series of 17 patients (34). At 4 years, progression-free survival was $42 \%$ and similar to matched-paired controls. Another taxane derivative, cabazitaxel, was also tested in a Phase II trial (NCT01650285) in combination with radiotherapy after prostatectomy, the results of which are pending. Strategies combining chemotherapy and radiotherapy may result in increased toxicity, with no major improvement in terms of survival.

\section{Targeting the Androgen Receptor}

The androgen receptor (AR) predominantly acts as a transcription factor regulating the expression of genes that maintain cellular homeostasis and normal prostate function (35). Dihydrotestosterone (DHT) binds to the androgen receptor, which then translocates from the cytoplasm to the nucleus, where it binds target genes with an androgen response element (ARE) to provoke a transcriptional response (35). Gene fusions of AR-regulated promoter regions with regions encoding members of the ETS (erythroblast transformation-specific) family of transcription factors are found in $40-60 \%$ of localized cases of prostate cancer $(36,37)$. AR amplification, alternative splicing of the AR, post-translational modifications to the AR, alteration of factors that control AR expression, or somatic gainof-function mutations which are the hallmark of late-stage castration-resistant prostate cancer, are typically absent in 
TABLE 1 S Summary of the various molecules currently associated with post-prostatectomy radiotherapy, either in adjuvant situations on anatomopathological criteria (2 studies) or - in most cases - depending on the elevation in PSA after prostatectomy.

\begin{tabular}{|c|c|c|c|c|c|c|c|}
\hline $\begin{array}{l}\text { Systemic } \\
\text { treatment }\end{array}$ & Study ID & Population & Study Arm & Radiotherapy & Outcomes Results & Recruitment & Results \\
\hline $\begin{array}{l}\text { mTOR } \\
\text { inhibitor }\end{array}$ & $\begin{array}{l}\text { NCT01548807 } \\
\text { Phase I } \\
\text { (5-7,5-10mg) }\end{array}$ & $\begin{array}{l}\text { Biochemical recurrence after } \\
\text { prostatectomy }\end{array}$ & Rapamycin + RT & 66,6Gy/37F IMRT Daily CBCT & $10 \mathrm{mg}$ is safe & Completed & Published (31) \\
\hline $\begin{array}{l}\text { Abirateron } \\
\text { acetate (AA) }\end{array}$ & $\begin{array}{l}\text { NCT01780220 Phase I,II } \\
\text { (CARLHA) }\end{array}$ & $\begin{array}{l}\text { Biochemical recurrence after } \\
\text { partial response }\end{array}$ & $\begin{array}{l}\text { A: AA-Prednisolone-ADT- } \\
\text { RTB: AA-Prednisolone-RT }\end{array}$ & $\begin{array}{l}\text { Prostate bed radiotherapy IMRT 66Gy/ } \\
33 \mathrm{~F}\end{array}$ & $\begin{array}{l}\text { B: not recommended } \\
\text { Dose: } 750 \mathrm{mg}\end{array}$ & Completed & Published (19) \\
\hline Enzalutamide & $\begin{array}{l}\text { NCT02057939 Phase II( } \\
\text { STREAM) }\end{array}$ & $\begin{array}{l}\text { Biochemical relapse after partial } \\
\text { response }\end{array}$ & Enza-ADT-RT & 66Gy/33F & 2-year PFS: 65\% & Completed & Published (20) \\
\hline Enzalutamide & $\begin{array}{l}\text { NCT02203695 Phase II (SALV- } \\
\text { ENZA) }\end{array}$ & $\begin{array}{l}\text { Biochemical relapse after partial } \\
\text { response }\end{array}$ & $\begin{array}{l}\text { A: RT-PlaceboB: RT- } \\
\text { Enzalutamide }\end{array}$ & $\begin{array}{l}66,6-70,2 \text { Gy } \\
\text { (daily placebo/enzlutamide and } 2 \\
\text { months after and before }\end{array}$ & $\begin{array}{l}\text { FFPP (freedom from } \\
\text { PSA progression) }\end{array}$ & Not recruiting & Not published \\
\hline Enzalutamide & $\begin{array}{l}\text { NCT03809000 } \\
\text { Phase II } \\
\text { (STEEL) }\end{array}$ & $\begin{array}{l}\text { Biochemical relapse after } \\
\text { prostatectomy }\end{array}$ & A: Enza-ADT-RTB: ADT-RT & 66-70.2 Gy & PFS & Recruiting & Not published \\
\hline Apalutamide & $\begin{array}{l}\text { NCT03311555 Phase II } \\
\text { (STARTAR) }\end{array}$ & $\begin{array}{l}\text { Biochemical complete response } \\
\text { after radical prostatectomy }\end{array}$ & $\begin{array}{l}\text { Apalutamide-ADT-RT + } \\
\text { adjuvant cocetaxel }\end{array}$ & $\begin{array}{l}\text { 66-74 Gy in 1,8-2 Gy daily fractions } \\
\text { over a total of 6-8 weeks }\end{array}$ & PFS & Not recruiting & Not published \\
\hline Apalutamide & $\begin{array}{l}\text { NCT04181203 } \\
\text { Phase III } \\
\text { (CARLHA-2) }\end{array}$ & $\begin{array}{l}\text { High-risk postprostatectomy } \\
\text { biochemically relapsed prostate } \\
\text { cancer patients }\end{array}$ & $\begin{array}{l}\text { A: apalutamide-RT-ADTB: } \\
\text { RT-ADT }\end{array}$ & $\begin{array}{l}\text { Prostate bed: 66Gy/33FPelvic node: } \\
56,1 \text { Gy/33FSIB } 69,3 / 33 \text { F to local } \\
\text { relapse (TEP/RM) }\end{array}$ & PFS & Recruiting & Not published \\
\hline Apalutamide & NCT03899077 Phase II (SAVE) & $\begin{array}{l}\text { Biochemical progression after } \\
\text { radical prostatectomy }\end{array}$ & $\begin{array}{l}\text { A: ADT-RTB: ADT-RT- } \\
\text { Apalutamide }\end{array}$ & NA & $\begin{array}{l}\text { EPIC-26 sexual } \\
\text { domain score }\end{array}$ & Recruiting & Not published \\
\hline Apalutamide & $\begin{array}{l}\text { NCT03371719NRG-GU006 } \\
\text { Phase II (BALANCE) }\end{array}$ & $\begin{array}{l}\text { Biochemical progression after } \\
\text { radical prostatectomy }\end{array}$ & $\begin{array}{l}\text { A: RT-placeboB: RT- } \\
\text { apalutamide }\end{array}$ & NA & $\begin{array}{l}\text { bPFS2 }{ }^{\text {nd }} \text { : stratification } \\
\text { by PAM50 gene } \\
\text { expression }\end{array}$ & Not recruiting & Not published \\
\hline $\begin{array}{l}\text { AA } \\
\text { +Apalutamide }\end{array}$ & $\begin{array}{l}\text { NCT03141671 Phase II } \\
\text { (FORMULA-509) }\end{array}$ & $\begin{array}{l}\text { Rising PSA after prostatectomy } \\
\text { with adverse features }\end{array}$ & $\begin{array}{l}\text { A: ADT-AA-apalutamide-RTB: } \\
\text { ADT-RT }\end{array}$ & NA & PFS & Not recruiting & Not published \\
\hline $\begin{array}{l}\text { Docetaxel } \\
\text { Sunitinib }\end{array}$ & NCT00734851 Phase II & Rising PSA after prostatectomy & $\begin{array}{l}4 \text { cycles D1-D21:Docetaxel- } \\
\text { Sunitinib D1-D14 }\end{array}$ & $\begin{array}{l}\text { Radiotherapy after docetaxel } \\
\text { sunitinib66Gy/33F }\end{array}$ & PFS & Completed & Published (32) \\
\hline Satraplatin & $\begin{array}{l}\text { NCT00480623 } \\
\text { Phase I }\end{array}$ & Rising PSA after prostatectomy & Satraplatin+RT concomittant & NA & DMTDLT & Completed & Not published \\
\hline Taxotere & NCT00480857Phase II & Rising PSA after prostatectomy & $\begin{array}{l}\text { Docetaxel 20mg/m2 weekly } \\
\text { during RT }\end{array}$ & $64,9-70.3$ to tumor bed & $\begin{array}{l}\text { No increase in } \\
\text { toxicityNo clinical } \\
\text { benefit }\end{array}$ & Completed & Published (33) \\
\hline Cabazitaxel & NCT01650285 & $\begin{array}{l}\text { Pathological determined stage } 3 \\
\text { and/or PSA rising }\end{array}$ & CabazitaxelDay $1,22,43$ & 64,8 Gy IMRTAdjuvant & DMT & Completed & Not published \\
\hline Ixabepilone & NCT01079793 & Pathological determined stage 3 & |xabepilone IB D1-D8D1=D21 & IMRTAdjuvant & DMT & Closed & Closed \\
\hline Metformin & $\begin{array}{l}\text { NCT02945813 Phase II } \\
\text { PROMET }\end{array}$ & Rising PSA after prostatectomy & $\begin{array}{l}\text { A: Metformin } 850 \mathrm{mg} / 12 \mathrm{~h}+ \\
\text { RTB: RT }\end{array}$ & 70Gy/35F & $\begin{array}{l}\text { TTP (time to } \\
\text { progression) }\end{array}$ & Completed & Not published \\
\hline
\end{tabular}

NA, not assessable. 
localized cases of prostate cancer (35). This dependence on AR makes localized prostate cancer highly sensitive to blockading AR signaling by drugs that target DHT production, such as LHRH agonists, or CYP17A1 inhibitors, such as abiraterone acetate, or drugs directly inhibiting the AR such as enzalutamide, darolutamide, or apalutamide.

The interaction between androgens and their receptor triggers intra- and interchromosomal rearrangements by double-stranded breaks. The fusion genes generated this way first initiate, and then promote, prostate cancer (38). This is the case, for example, for the TMPRSS2-ERG fusion gene, which results from a rearrangement mediated by topoisomerase $2 \mathrm{~B}$, itself regulated by the androgen receptor pathway (39). However, radiotherapy increases the expression of androgen receptors and stimulates their activity both in vitro and in vivo, where an increase in the level of hK2, a protein involved in the androgen pathway, is measured in the serum of patients treated with radiotherapy (32). In addition, upregulation of the TMPRSS2 gene mentioned above is observed in the irradiated prostate cell lines. It is therefore understood that radiotherapy may stimulate the androgen receptor pathway, which is thwarted by androgen suppression. Moreover, AR targeting impairs DNA double-strand break repair by inhibiting non-homologous end joining $(17,18)$, thereby increasing the radiosensitivity of prostate cancer cells.

Two randomized phase 3 studies, GETUG 16 and RTOG 9601, showed there was a strong clinical benefit to combining ADT and prostate bed radiotherapy $(4,5)$. As preclinical experiments showed that AR-targeting drugs such as enzalutamide are better radiosensitizers than ADT (33), it is expected that combining novel AR-targeting agents may increase the benefits of salvage radiotherapy. Several phase 1 and phase 2 trials have already investigated the combination of radiotherapy and secondgeneration hormone therapy: abiraterone acetate (AA), enzalutamide, apalutamide, and darolutamide (Table 1). The phase 1 CARLHA study was the first to combine salvage prostate bed radiotherapy and AA with or without LH-RH agonists (31). When AA was administered without LH-RH agonists, only $78 \%$ achieved castration levels. AA combined with SRT and goserilin did not increase pelvic toxicity but led to an unexpectedly high frequency of grade 3 liver toxicity. The phase II recommended dose of AA combined with goserelin and SRT was $750 \mathrm{mg}$. Phase 2 results are pending. Enzalutamide was also evaluated in combination with salvage prostate bed radiotherapy (40). Grade 3 toxicities, mostly fatigue and hypertension, were observed in $29 \%$ of patients. After a median follow-up time of 37.5 months, 2-year progression-free survival was $65 \%$. Other phase 2 studies are ongoing or closed to accrual. The randomized phase 3 study that compares salvage prostate bed and lymph node radiotherapy combined with 6 months of ADT +/- apalutamide, CARLHA 2 GETUG 33 (NCT04181203), is actively recruiting patients.

\section{Targeting the Pi3K/Akt/mTOR Pathway}

The mammalian target of rapamycin (mTOR) is a protein central to the regulation of cell metabolism and proliferation. mTOR is a downstream effector in the phosphatidylinositol 3-kinase/protein kinase B PI3K/AKT pathway, which regulates metabolism, protein synthesis, growth, cell cycle progression, and survival (41).
The Pi3K/AKT pathway is the most frequently activated intracellular signaling pathway in prostate cancer, responsible for important signals for malignant transformation, tumor progression, and metastatic invasion. PI3K/AKT is negatively regulated by the PTEN tumor suppressor (phosphatase and tensin homolog) and PTEN deletions are observed in up to $20 \%$ of localized cases of prostate cancer. The PI3KAKT crosstalk with the androgen receptor (AR) pathway and AR signaling blockade results in compensatory activation of the PI3KAKT pathway (42). The PI3KAKT pathway also has close links with the RAS/RAF/ MEK/ERK pathway and with VEGF (41).

The Pi3K/Akt/mTOR pathway plays a key role in radioresistance through different mechanisms: increased metabolism and proliferation (43), increased DNA repair as AKT regulates DNA-PK activity (44), and mTOR signaling which also plays a key role in hypoxia-triggered angiogenesis and HIFlalpha overexpression (45).

Given the role of PI3K and mTOR in the response of prostate cancer cells to radiation and hypoxia, preclinical studies investigated whether PI3K/AKT/mTOR inhibitors radiosensitized prostate cancer cells of different PTEN status. Several drugs targeting the PI3K/AKT pathway have been developed: Pi3K inhibitors (LY294002, WORTMANNIN, BKM120, GSK2636771), AKT inhibitors (Palomid 539, erufosine, perifosine, ipatasertib), mTOR inhibitors (sirolimus, temsirolimus, everolimus) and dual PI3K/mTOR inhibitors (BEZ235, PI103, GDC-0980). The radiosensitizing properties of these agents have been investigated in several studies in prostate cancer models (46-48). Because of the non-selective profiles of certain drugs in this family, especially with regard to DNA repair, the combination may however be toxic.

The combination of the mTOR inhibitor everolimus and prostate bed radiotherapy without adding ADT was tested in a phase I clinical study (49). The maximum tolerated dose of everolimus in combination with fractionated post-prostatectomy radiation therapy was $10 \mathrm{mg}$ daily, leading to no unexpected toxicity. An undetectable prostate-specific antigen nadir was achieved in more than $50 \%$ of patients but information on the PTEN status of responding patients was lacking. With the promising results of ipatasertib in metastatic castration-resistant prostate cancer (50), this area of research warrants further investigation.

\section{Targeting DNA Repair Pathways}

DNA damage response (DDR) genes play an important role in prostate cancer. Men with germline BRCA2 mutations have a higher risk of aggressive prostate cancer because of MYC activation in combination with inactivation of TP53 and PTEN (51), leading to worse clinical outcomes (52). DDR also plays a major role in the response to radiotherapy, where DNA double strand-breaks are mostly repaired by homologous recombination (HR) and non-homologous end joining (NHEJ). Drugs targeting DDR are very potent radiosensitizers but may increase the likelihood of normal tissue toxicity. In cells lacking efficient HR, such as BRCA2-deficient cells, other DNA repair pathways, such as base excision repair (BER), are responsible for high-fidelity DDR. Combining inhibitors of BER such as polyADP ribosylpolymerase (PARP) inhibitors may therefore 
radiosensitize HR-deficient cells while not radiosensitizing normal cells with regular HR function. Several PARPi, such as veliparib, olaparib, rucaparib, or talazoparib, were tested in combination with irradiation in prostate cancer models [reviewed in (53)]. Encouraging results suggest increased radiosensitization and limited combined toxicity. To date, no clinical studies have currently addressed the combination of PARPi or any drug targeting DDR in combination with salvage prostate bed radiotherapy.

\section{Targeting Hypoxia and Glucose Metabolism}

Many primary tumors have low levels of molecular oxygen. Hypoxia plays a role in both dissemination, by increasing the genes involved in metastasis, and angiogenesis (e.g. VEGF), and hypoxic tumors respond poorly to radiotherapy. Prostate cancer is strongly hypoxic $(54,55)$ and a hypoxic signature is a predictor of poor response to radiotherapy $(22,23)$. The oxic status of the prostate bed following prostatectomy has not been explored, but it is expected that lack of vasculature will render residual tumor cells hypoxic. There are several mechanisms to combat hypoxia: increase oxygen with hyperbaric oxygen or use hypoxic cell radiosensitizers such as tirapazamine for example. Another mechanism is to reduce glucose consumption to force aerobic cells to consume more glucose and reduce glucose concentrations in lesser perfused cells. One of the molecules studied in this sense is metformin, which has already shown its clinical value in retrospective series (56). The SAKK 08/15 - PROMET/GETUG 34 trial (NCT02945813) is a randomized phase II trial that closed recently. It tested salvage radiotherapy $+/$ - metformin in patients with prostate cancer relapsing after prostatectomy. Other inexpensive drugs, such as menadione, could be repurposed to serve as novel radiosensitizers in the treatment of hypoxic prostate cancer (57).

\section{PERSPECTIVES}

Not all biochemically-relapsing patients are potential candidates for salvage radiotherapy combined with radiosensitizing drugs (58). The median time from the time of PSA level elevation to the occurrence of metastases is 8 years (59). Strengthening prostate bed radiotherapy by adding drugs can be detrimental in fragile patients with a limited risk of dying of their biochemically-relapsing prostate cancer. The overall benefits of ADT combined with SRT are lost in patients with a lower PSA because of ADT-related cardiovascular toxicity (60). A key point is therefore patient selection, and transcriptomic signatures can help select patients at higher risk of relapse following salvage therapy (28). The European Association of Urology high-risk group of patients with a biochemical relapse following prostatectomy (PSA-doubling time less than 1 year or ISUP grade 4-5 tumors) (58) could help both identify the patients who need treatment intensification and in particular define the use of novel agents in addition to RT+/-ADT. To improve patient selection, the NRG GU006 (NCT03371719) trial is stratifying patients based on their transcriptomic signature to evaluate the benefits of apalutamide combined with ADT and prostate bed radiotherapy. Similarly, genomic characterization of the prostate tumor may help select the best radiosensitizing drug, such as DNA repair inhibitors or immunotherapy in DDR-deficient tumors, or AKT pathway inhibitors in PTEN mutated tumors. As the overall prognosis of biochemically-relapsing patients is good, radiosensitizing candidates should present a strong benefits/risk ratio, which precludes toxic combinations such as certain PI3K inhibitors or chemotherapeutic agents. Lastly, improved phenotypic imaging may help better reduce the target volumes and thereby decrease the likelihood of combined toxicity.

\section{CONCLUSION}

In this review, we have described therapeutic pathways under investigation in the management of patients experiencing biochemical failure after prostatectomy. However, clinical efficacy remains to be demonstrated for many of the molecules and signaling pathways. In the near future, given the large number of trials, the role of AR-targeting agents should be given a significant role in the management of these patients. Although therapeutic control is an essential point, it is important to take the absence of additional toxicity into account in these long surviving patients with few symptoms.

\section{DATA AVAILABILITY STATEMENT}

The original contributions presented in the study are included in the article/supplementary material. Further inquiries can be directed to the corresponding author.

\section{AUTHOR CONTRIBUTIONS}

AC and SS contributed to conception and design of the study. AC wrote the first draft of the manuscript. SS, PS, IL, and FS wrote sections of the manuscript. All authors contributed to manuscript revision, read, and approved the submitted version.

\section{FUNDING}

SS: coordinating investigator of the GETUG 33 CARLHA 2 study funded by Janssen. Research grants: Astellas, AstraZeneca. Expertise and advisory boards: Bayer, Ipsen, BoucharaRecordati, Takeda.

\section{ACKNOWLEDGMENTS}

Valentine Guimas, Loig Vaugier, Emmanuel Rio for fruitful discussions. 


\section{REFERENCES}

1. Thoms J, Goda JS, Zlotta AR, Fleshner NE, van der Kwast TH, Supiot S, et al. Neoadjuvant Radiotherapy for Locally Advanced and High-Risk Prostate Cancer. Nat Rev Clin Oncol (2011) 8:107-13. doi: 10.1038/nrclinonc.2010.207

2. Bolla M, van Poppel H, Collette L, van Cangh P, Vekemans K, Da Pozzo L, et al. Postoperative Radiotherapy After Radical Prostatectomy: A Randomised Controlled Trial (EORTC Trial 22911). Lancet (2005) 366:572-8. doi: 10.1016/S0140-6736(05)67101-2

3. Swanson GP, Hussey MA, Tangen CM, Chin J, Messing E, Canby-Hagino E, et al. Predominant Treatment Failure in Postprostatectomy Patients Is Local: Analysis of Patterns of Treatment Failure in SWOG 8794. J Clin Oncol (2007) 25:2225-9. doi: 10.1200/JCO.2006.09.6495

4. Carrie C, Magne N, Burban-Provost P, Sargos P, Latorzeff I, Lagrange JL, et al. Short-Term Androgen Deprivation Therapy Combined With Radiotherapy as Salvage Treatment After Radical Prostatectomy for Prostate Cancer (GETUG-AFU 16): A 112-Month Follow-Up of a Phase 3, Randomised Trial. Lancet Oncol (2019) 20:1740-9. doi: 10.1016/S1470-2045(19)30486-3

5. Shipley WU, Seiferheld W, Lukka HR, Major PP, Heney NM, Grignon DJ, et al. Radiation With or Without Antiandrogen Therapy in Recurrent Prostate Cancer. N Engl J Med (2017) 376:417-28. doi: 10.1056/ NEJMoa1607529

6. Cornford P, van den Bergh RCN, Briers E, Van den Broeck T, Cumberbatch MG, De Santis M, et al. EAU-EANM-ESTRO-ESUR-SIOG Guidelines on Prostate Cancer. Part II-2020 Update: Treatment of Relapsing and Metastatic Prostate Cancer. Eur Urol (2021) 79:263-82. doi: 10.1016/ j.eururo.2020.09.046

7. Tendulkar RD, Agrawal S, Gao T, Efstathiou JA, Pisansky TM, Michalski JM, et al. Contemporary Update of a Multi-Institutional Predictive Nomogram for Salvage Radiotherapy After Radical Prostatectomy. J Clin Oncol (2016) 34:3648-54. doi: 10.1200/JCO.2016.67.9647

8. De Meerleer G, Berghen C, Briganti A, Vulsteke C, Murray J, Joniau S, et al. Elective Nodal Radiotherapy in Prostate Cancer. Lancet Oncol (2021) 22: e348-e57. doi: 10.1016/S1470-2045(21)00242-4

9. Supiot S, Vaugier L, Pasquier D, Buthaud X, Magné N, Peiffert D, et al. OLIGOPELVIS GETUG P07, A Multicenter Phase II Trial of Combined High-Dose Salvage Radiotherapy and Hormone Therapy in Oligorecurrent Pelvic Node Relapses in Prostate Cancer. Eur Urol (2021) 80(4):405-414. doi: 10.1016/j.eururo.2021.06.010

10. Pollack A, Karrison TG, Balogh AG Jr, Low D, Bruner DW, Wefel JS, et al. Short Term Androgen Deprivation Therapy Without or With Pelvic Lymph Node Treatment Added to Prostate Bed Only Salvage Radiotherapy: The NRG Oncology/RTOG 0534 SPPORT Trial. Int J Radiat Oncol Biol Phys (2018) 102:1605. doi: 10.1016/j.ijrobp.2018.08.052

11. Byrne K, Eade T, Kneebone A, Guo L, Hsiao E, Schembri G, et al. Delineating Sites of Failure Following Post-Prostatectomy Radiation Treatment Using 68ga-PSMA-PET. Radiother Oncol (2018) 126:244-8. doi: 10.1016/j.radonc. 2017.10.022

12. De Bari B, Mazzola R, Aiello D, Aloi D, Gatta R, Corradini S, et al. (68ga)PSMA-PET/CT for the Detection of Postoperative Prostate Cancer Recurrence: Possible Implications on Treatment Volumes for Radiation Therapy. Cancer/ Radiothérapie (2019) 23:194-200. doi: 10.1016/j.canrad.2018.09.003

13. Rowe LS, Harmon S, Horn A, Shankavaram U, Roy S, Ning H, et al. Pattern of Failure in Prostate Cancer Previously Treated With Radical Prostatectomy and Post-Operative Radiotherapy: A Secondary Analysis of Two Prospective Studies Using Novel Molecular Imaging Techniques. Radiat Oncol (2021) 16:32. doi: 10.1186/s13014-020-01733-x

14. Bayley A, Rosewall T, Craig T, Bristow R, Chung P, Gospodarowicz M, et al. Clinical Application of High-Dose, Image-Guided Intensity-Modulated Radiotherapy in High-Risk Prostate Cancer. Int J Radiat Oncol Biol Phys (2010) 77:477-83. doi: 10.1016/j.ijrobp.2009.05.006

15. Vaugier L, Palpacuer C, Rio E, Goineau A, Pasquier D, Buthaud X, et al. Early Toxicity of a Phase II Trial of Combined Salvage Radiotherapy and Hormone Therapy in Oligometastatic Pelvic Node Relapses of Prostate Cancer (OLIGOPElVIS GETUG P07). Int J Radiat Oncol Biol Phys (2018) 103 (5):1061-67. doi: 10.1016/j.ijrobp.2018.12.020

16. Milosevic M, Chung P, Parker C, Bristow R, Toi A, Panzarella T, et al. Androgen Withdrawal in Patients Reduces Prostate Cancer Hypoxia:
Implications for Disease Progression and Radiation Response. Cancer Res (2007) 67:6022-5. doi: 10.1158/0008-5472.CAN-07-0561

17. Polkinghorn WR, Parker JS, Lee MX, Kass EM, Spratt DE, Iaquinta PJ, et al. Androgen Receptor Signaling Regulates DNA Repair in Prostate Cancers. Cancer Discov (2013) 3:1245-53. doi: 10.1158/2159-8290.CD-13-0172

18. Goodwin JF, Schiewer MJ, Dean JL, Schrecengost RS, de Leeuw R, Han S, et al. A Hormone-DNA Repair Circuit Governs the Response to Genotoxic Insult. Cancer Discov (2013) 3:1254-71. doi: 10.1158/2159-8290.CD-13-0108

19. Fraser M, Sabelnykova VY, Yamaguchi TN, Heisler LE, Livingstone J, Huang $\mathrm{V}$, et al. Genomic Hallmarks of Localized, Non-Indolent Prostate Cancer. Nature (2017) 541:359-64. doi: 10.1038/nature20788

20. Houlahan KE, Shiah Y-J, Gusev A, Yuan J, Ahmed M, Shetty A, et al. Genome-Wide Germline Correlates of the Epigenetic Landscape of Prostate Cancer. Nat Med (2019) 25:1615-26. doi: 10.1038/s41591-019-0579-Z

21. Espiritu SMG, Liu LY, Rubanova Y, Bhandari V, Holgersen EM, Szyca LM, et al. The Evolutionary Landscape of Localized Prostate Cancers Drives Clinical Aggression. Cell (2018) 173:1003-13.e15. doi: 10.1016/j.cell. 2018.03.029

22. Yang L, Roberts D, Takhar M, Erho N, Bibby BAS, Thiruthaneeswaran N, et al. Development and Validation of a 28-Gene Hypoxia-Related Prognostic Signature for Localized Prostate Cancer. EBioMedicine (2018) 31:182-9. doi: 10.1016/j.ebiom.2018.04.019

23. Lalonde E, Ishkanian AS, Sykes J, Fraser M, Ross-Adams H, Erho N, et al. Tumour Genomic and Microenvironmental Heterogeneity for Integrated Prediction of 5-Year Biochemical Recurrence of Prostate Cancer: A Retrospective Cohort Study. Lancet Oncol (2014) 15:1521-32. doi: 10.1016/ S1470-2045(14)71021-6

24. Berlin A, Lalonde E, Sykes J, Zafarana G, Chu KC, Ramnarine VR, et al. NBN Gain Is Predictive for Adverse Outcome Following Image-Guided Radiotherapy for Localized Prostate Cancer. Oncotarget (2014) 5 (22):11081-90. doi: 10.18632/oncotarget.2404

25. Berlin A, Murgic J, Hosni A, Pintilie M, Salcedo A, Fraser M, et al. Genomic Classifier for Guiding Treatment of Intermediate-Risk Prostate Cancers to Dose-Escalated Image Guided Radiation Therapy Without Hormone Therapy. Int J Radiat Oncol Biol Phys (2019) 103:84-91. doi: 10.1016/ j.ijrobp.2018.08.030

26. Dal Pra A, Locke JA, Borst G, Supiot S, Bristow RG. Mechanistic Insights Into Molecular Targeting and Combined Modality Therapy for Aggressive, Localized Prostate Cancer. Front Oncol (2016) 6:24. doi: 10.3389/ fonc.2016.00024

27. Kamran SC, Efstathiou JA. Current State of Personalized Genitourinary Cancer Radiotherapy in the Era of Precision Medicine. Front Oncol (2021) 11. doi: 10.3389/fonc.2021.675311

28. Feng FY, Huang H-C, Spratt DE, Zhao S, Sandler HM, Simko JP, et al. Validation of a 22-Gene Genomic Classifier in Patients With Recurrent Prostate Cancer: An Ancillary Study of the NRG/RTOG 9601 Randomized Clinical Trial. JAMA Oncol (2021) 7:544-52. doi: 10.1001/jamaoncol. 2020.7671

29. Wedge DC, Gundem G, Mitchell T, Woodcock DJ, Martincorena I, Ghori M, et al. Sequencing of Prostate Cancers Identifies New Cancer Genes, Routes of Progression and Drug Targets. Nat Genet (2018) 50:682-92. doi: 10.1038/ s41588-018-0086-z

30. Armstrong AJ, Halabi S, Healy P, Lee WR, Koontz BF, Moul JW, et al. A Phase 2 Multimodality Trial of Docetaxel/Prednisone With Sunitinib Followed by Salvage Radiation Therapy in Men With PSA Recurrent Prostate Cancer After Radical Prostatectomy. Prostate Cancer Prostatic Dis (2016) 19:100-6. doi: 10.1038/pcan.2015.59

31. Supiot S, Campion L, Pommier P, Dore M, Palpacuer C, Racadot S, et al. Combined Abiraterone Acetate Plus Prednisone, Salvage Prostate Bed Radiotherapy and LH-RH Agonists (CARLHA-GEP12) in BiochemicallyRelapsing Prostate Cancer Patients Following Prostatectomy: A Phase I Study of the GETUG/GEP. Oncotarget (2018) 9(31):22147-57. doi: 10.18632/ oncotarget.25189

32. Spratt DE, Evans MJ, Davis BJ, Doran MG, Lee MX, Shah N, et al. Androgen Receptor Upregulation Mediates Radioresistance After Ionizing Radiation. Cancer Res (2015) 75:4688-96. doi: 10.1158/0008-5472.CAN-15-0892

33. Ghashghaei M, Paliouras M, Heravi M, Bekerat H, Trifiro M, Niazi TM, et al. Enhanced Radiosensitization of Enzalutamide via Schedule Dependent 
Administration to Androgen-Sensitive Prostate Cancer Cells. Prostate (2018) 78:64-75. doi: 10.1002/pros.23445

34. Jackson WC, Feng FY, Daignault S, Hussain M, Smith D, Cooney K, et al. A Phase 2 Trial of Salvage Radiation and Concurrent Weekly Docetaxel After a Rising Prostate-Specific Antigen Level After Radical Prostatectomy. Adv Radiat Oncol (2016) 1:59-66. doi: 10.1016/j.adro.2015.11.001

35. Rebello RJ, Oing C, Knudsen KE, Loeb S, Johnson DC, Reiter RE, et al. Prostate Cancer. Nat Rev Dis Primers (2021) 7:9. doi: 10.1038/s41572-02000243-0

36. Tomlins SA, Rhodes DR, Perner S, Dhanasekaran SM, Mehra R, Sun X-W, et al. Recurrent Fusion of TMPRSS2 and ETS Transcription Factor Genes in Prostate Cancer. Science (2005) 310:644-8. doi: 10.1126/science.1117679

37. Carver BS, Tran J, Chen Z, Carracedo-Perez A, Alimonti A, Nardella C, et al. ETS Rearrangements and Prostate Cancer Initiation. Nature (2009) 457:E1-E. doi: $10.1038 /$ nature 07738

38. Lin C, Yang L, Tanasa B, Hutt K, Ju B-g, Ohgi KA, et al. Nuclear ReceptorInduced Chromosomal Proximity and DNA Breaks Underlie Specific Translocations in Cancer. Cell (2009) 139:1069-83. doi: 10.1016/ j.cell.2009.11.030

39. Haffner MC, Aryee MJ, Toubaji A, Esopi DM, Albadine R, Gurel B, et al. Androgen-Induced TOP2B-Mediated Double-Strand Breaks and Prostate Cancer Gene Rearrangements. Nat Genet (2010) 42:668-75. doi: 10.1038/ ng.613

40. Bitting RL, Healy P, George DJ, Anand M, Kim S, Mayer T, et al. Phase II Trial of Enzalutamide and Androgen Deprivation Therapy With Salvage Radiation in Men With High-Risk Prostate-Specific Antigen Recurrent Prostate Cancer: The STREAM Trial. Eur Urol Oncol (2020) S2588-9311(20):30020-1. doi: 10.1016/j.euo.2020.01.005

41. Chang L, Graham PH, Ni J, Hao J, Bucci J, Cozzi PJ, et al. Targeting PI3K/Akt/ mTOR Signaling Pathway in the Treatment of Prostate Cancer Radioresistance. Crit Rev Oncol/Hematol (2015) 96:507-17. doi: 10.1016/ j.critrevonc.2015.07.005

42. Carver Brett S, Chapinski C, Wongvipat J, Hieronymus H, Chen Y, Chandarlapaty S, et al. Reciprocal Feedback Regulation of PI3K and Androgen Receptor Signaling in PTEN-Deficient Prostate Cancer. Cancer Cell (2011) 19:575-86. doi: 10.1016/j.ccr.2011.04.008

43. Schuurbiers OC, Kaanders JH, van der Heijden HF, Dekhuijzen RP, Oyen WJ, Bussink J. The PI3-K/AKT-Pathway and Radiation Resistance Mechanisms in Non-Small Cell Lung Cancer. J Thorac Oncol (2009) 4:761-7. doi: 10.1097/ JTO.0b013e3181a1084f

44. Toulany M, Kehlbach R, Florczak U, Sak A, Wang S, Chen J, et al. Targeting of AKT1 Enhances Radiation Toxicity of Human Tumor Cells by Inhibiting DNA-PKcs-Dependent DNA Double-Strand Break Repair. Mol Cancer Ther (2008) 7:1772-81. doi: 10.1158/1535-7163.MCT-07-2200

45. Gupta AK, Cerniglia GJ, Mick R, Ahmed MS, Bakanauskas VJ, Muschel RJ, et al. Radiation Sensitization of Human Cancer Cells In Vivo by Inhibiting the Activity of PI3K Using Ly294002. Int J Radiat Oncol Biol Phys (2003) 56:84653. doi: 10.1016/S0360-3016(03)00214-1

46. Diaz R, Nguewa PA, Diaz-Gonzalez JA, Hamel E, Gonzalez-Moreno O, Catena R, et al. The Novel Akt Inhibitor Palomid 529 (P529) Enhances the Effect of Radiotherapy in Prostate Cancer. Br J Cancer (2009) 100:932-40. doi: 10.1038/sj.bjc.6604938

47. Gao Y, Ishiyama H, Sun M, Brinkman KL, Wang X, Zhu J, et al. The Alkylphospholipid, Perifosine, Radiosensitizes Prostate Cancer Cells Both In Vitro and In Vivo. Radiat Oncol (Lond Engl) (2011) 6:39-. doi: 10.1186/1748717X-6-39

48. Potiron VA, Abderrahmani R, Giang E, Chiavassa S, Di Tomaso E, Maira SM, et al. Radiosensitization of Prostate Cancer Cells by the Dual PI3K/mTOR Inhibitor BEZ235 Under Normoxic and Hypoxic Conditions. Radiother Oncol (2013) 106:138-46. doi: 10.1016/j.radonc.2012.11.014

49. Narayan V, Vapiwala N, Mick R, Subramanian P, Christodouleas JP, Bekelman JE, et al. Phase 1 Trial of Everolimus and Radiation Therapy for Salvage Treatment of Biochemical Recurrence in Prostate Cancer Patients Following Prostatectomy. Int J Radiat Oncol Biol Phys (2017) 97:355-61. doi: 10.1016/j.ijrobp.2016.10.013
50. Sweeney C, Bracarda S, Sternberg CN, Chi KN, Olmos D, Sandhu S, et al. Ipatasertib Plus Abiraterone and Prednisolone in Metastatic CastrationResistant Prostate Cancer (IPATential150): A Multicentre, Randomised, Double-Blind, Phase 3 Trial. Lancet (2021) 398:131-42. doi: 10.1016/S01406736(21)00580-8

51. Taylor RA, Fraser M, Livingstone J, Espiritu SMG, Thorne H, Huang V, et al. Germline BRCA2 Mutations Drive Prostate Cancers With Distinct Evolutionary Trajectories. Nat Commun (2017) 8:13671. doi: 10.1038/ ncomms 13671

52. Castro E, Goh C, Olmos D, Saunders E, Leongamornlert D, Tymrakiewicz M, et al. Germline BRCA Mutations Are Associated With Higher Risk of Nodal Involvement, Distant Metastasis, and Poor Survival Outcomes in Prostate Cancer. J Clin Oncol (2013) 31:1748-57. doi: 10.1200/JCO.2012.43.1882

53. Lesueur P, Chevalier F, Austry J-B, Waissi W, Burckel H, Noël G, et al. Poly(ADP-Ribose)-Polymerase Inhibitors as Radiosensitizers: A Systematic Review of Pre-Clinical and Clinical Human Studies. Oncotarget (2017) 8 (40):69105-24. doi: 10.18632/oncotarget.19079

54. Vergis R, Corbishley CM, Norman AR, Bartlett J, Jhavar S, Borre M, et al. Intrinsic Markers of Tumour Hypoxia and Angiogenesis in Localised Prostate Cancer and Outcome of Radical Treatment: A Retrospective Analysis of Two Randomised Radiotherapy Trials and One Surgical Cohort Study. Lancet Oncol (2008) 9:342-51. doi: 10.1016/S1470-2045(08)70076-7

55. Supiot S, Rousseau C, Dore M, Cheze-Le-Rest C, Kandel-Aznar C, Potiron V, et al. Evaluation of Tumor Hypoxia Prior to Radiotherapy in IntermediateRisk Prostate Cancer Using (18)F-Fluoromisonidazole PET/CT: A Pilot Study. Oncotarget (2018) 9:10005-15. doi: 10.18632/oncotarget.24234

56. Spratt DE, Zhang C, Zumsteg ZS, Pei X, Zhang Z, Zelefsky MJ. Metformin and Prostate Cancer: Reduced Development of Castration-Resistant Disease and Prostate Cancer Mortality. Eur Urol (2013) 63:709-16. doi: 10.1016/ j.eururo.2012.12.004

57. Bibby BAS, Thiruthaneeswaran N, Yang L, Pereira RR, More E, McArt DG, et al. Repurposing FDA Approved Drugs as Radiosensitizers for Treating Hypoxic Prostate Cancer. BMC Urol (2021) 21:96. doi: 10.1186/s12894-021-00856-x

58. Van den Broeck T, van den Bergh RCN, Briers E, Cornford P, Cumberbatch M, Tilki D, et al. Biochemical Recurrence in Prostate Cancer: The European Association of Urology Prostate Cancer Guidelines Panel Recommendations. Eur Urol Focus (2020) 6:231-4. doi: 10.1016/j.euf.2019.06.004

59. Pound CR, Partin AW, Eisenberger MA, Chan DW, Pearson JD, Walsh PC. Natural History of Progression After PSA Elevation Following Radical Prostatectomy. JAMA (1999) 281:1591-7. doi: 10.1001/jama.281.17.1591

60. Dess RT, Sun Y, Jackson WC, Jairath NK, Kishan AU, Wallington DG, et al. Association of Presalvage Radiotherapy PSA Levels After Prostatectomy With Outcomes of Long-Term Antiandrogen Therapy in Men With Prostate Cancer. JAMA Oncol (2020) 6:735-43. doi: 10.1001/jamaoncol.2020.0109

Conflict of Interest: SS: coordinating investigator of the GETUG 33 CARLHA 2 study funded by Janssen.

The remaining authors declare that the research was conducted in the absence of any commercial or financial relationships that could be construed as a potential conflict of interest.

Publisher's Note: All claims expressed in this article are solely those of the authors and do not necessarily represent those of their affiliated organizations, or those of the publisher, the editors and the reviewers. Any product that may be evaluated in this article, or claim that may be made by its manufacturer, is not guaranteed or endorsed by the publisher.

Copyright (๑ 2021 Cailleteau, Sargos, Saad, Latorzeff and Supiot. This is an openaccess article distributed under the terms of the Creative Commons Attribution License (CC BY). The use, distribution or reproduction in other forums is permitted, provided the original author(s) and the copyright owner(s) are credited and that the original publication in this journal is cited, in accordance with accepted academic practice. No use, distribution or reproduction is permitted which does not comply with these terms. 